\title{
In-Vivo and In-Vitro Anti-Inflammatory Activities of the Aqueous Extract of Di-Herbal Formulation (Euphorbia hirta and lactuca virosa)
}

\author{
*UWAYA, DO; OKAKWU, R; OMOZUWA, OP
}

\author{
Department of Science Laboratory Technology, Faculty of Life Sciences, University of Benin, Benin City, Benin City 300001, Nigeria \\ *Corresponding Author Email: dickson.uwaya@uniben.edu; udickson4christ@yahoo.com; Tel: (+234) 705-965-0758
}

\begin{abstract}
Euphorbia hirta and Lactuca virosa are medicinal plants that have been used in the cure and treatment of various diseases and for health care. This study aims at evaluating the anti-inflammatory activities of the aqueous extracts of Euphorbia hirta and Lactuca virosa plants. Albumin and histamine induced inflammation in mice and xylene induced ear edema were used for the in-vivo anti-inflammatory studies. Erythrocyte membrane stabilization and inhibition of protein denaturation assays were used for the in-vitro anti-inflammatory studies. Combined doses of 100 $\mathrm{mg} / \mathrm{kg}$ Euphorbia hirta and $50 \mathrm{mg} / \mathrm{kg}$ Lactuca virosa, $100 \mathrm{mg} / \mathrm{kg}$ Euphorbia hirta and $100 \mathrm{mg} / \mathrm{kg}$ Lactuca virosa, 100 $\mathrm{mg} / \mathrm{kg}$ Lactuca virosa only and $10 \mathrm{mg} / \mathrm{kg}$ diclofenac significantly reduced inflamed paw in mice $(\mathrm{P}<0.05)$ compared to control in albumin and histamine induced inflammatory test. Combined doses of $50 \mathrm{mg} / \mathrm{kg}$ Euphorbia hirta and 100 $\mathrm{mg} / \mathrm{kg}$ Lactuca virosa, $100 \mathrm{mg} / \mathrm{kg}$ Euphorbia hirta, $100 \mathrm{mg} / \mathrm{kg}$ Lactuca virosa significantly reduced xylene induced inflammation $(\mathrm{P}<0.001)$ compared to control. The extracts at $1 \mathrm{mg} / \mathrm{ml}, 2 \mathrm{mg} / \mathrm{ml}$ and $3 \mathrm{mg} / \mathrm{ml}$ significantly inhibited protein denaturation $(\mathrm{P}<0.001)$ and heat induced hemolysis of erythrocytes $(\mathrm{P}<0.0001)$. The plant extract of Euphorbia hirta and lactuca virosa possesses in-vivo and in-vivo anti-inflammatory effects.
\end{abstract}

\section{DOI: https://dx.doi.org/10.4314/jasem.v24i11.19}

Copyright: Copyright $\left({ }^{\circ} 2020\right.$ Uwaya et al. This is an open access article distributed under the Creative Commons Attribution License (CCL), which permits unrestricted use, distribution, and reproduction in any medium, provided the original work is properly cited.

Dates: Received: 10 October 2020; Revised: 11 November 2020; Accepted: 20 November 2020

Keywords: Euphorbia hirta, Lactuca virosa, anti-inflammatory, protein denaturation

Plants play a leading role in the health care system globally. It remained the pillar of medicinal revolution for a long time (Dar et al., (2017). The background of traditional medicine for years was been gotten from plants through which have been used to produce and give human with new medical therapies (WHO, 1998). Euphorbia hirta belongs to family Euphorbiaceae and commonly called asthma weed plant (Pranabesh et al., (2019). It is native to Central America. The plant is distributed throughout the tropical countries and wildly grown in low jungle areas, along roadside (Sunil et al., (2010). The plant is widely used to treat various ailment in traditional medicine. It has antiallergic, analgesic, anti-anaphylactic, anti-diarrheal, spasmogenic, anti-inflammatory, antioxidant, diuretic, anti-tumor and anxiolytic properties (Pranabesh et al., (2019). Lactuca virosa called wild lettuce or opium lettuce is a two-yearly herb that grows on the banks of rivers and wastelands to a height of 6 feet. It is cultivated in diverse areas of the world, such as Austria, France, Germany, Scotland and Nigeria. Traditionally, it is used for insomnia, restlessness, irritable cough, priapism, dysmenorrhea, nymphomania and muscular or articular pains (Darkwa and Darkwa, (2013). Therefore, the objective of this study is to evaluate the anti-inflammatory activities of the aqueous extracts of Euphorbia hirta and Lactuca virosa plants

\section{MATERIALS AND METHOD}

Euphobia hirta plant was collected from the vicinity of the University of Benin in Ovia North East Local Government Area, Edo State, Nigeria. Lactuca virosa plant was collected from Ife-East Local Government Area, Ile-ife, osun state, Nigeria. The two plants were identified and authenticated by Dr. H. A. Akinnibosun in the Department of Plant and Biotechnology, Faculty of life Sciences, University of Benin, Benin City, Edo State, Nigeria

Preparation of Plant Materials: Euphobia hirta whole plant was washed and air dried for 14 days in the Department of Science laboratory Technology, University of Benin, Benin City. The plant was grinded into powder using an impact mill. The powdered plant material was macerated for 24 hours after which filtration was done. Lactuca virosa leaves were washed and chopped. The chopped leaves were blended with distilled water and filtration was done. The filtrate of both plants was then freeze dried using a freeze drier at the Energy Centre, University of Benin. 
Experimental Animals: Eighty-four mice of either sex weighing 20-35 g were purchased from a commercial animal house in Ibadan. The animals were allowed two weeks acclimatization in the animal facility of the Department of animal and environmental biology, Faculty of Life Sciences, University of Benin, Benin City. They were allowed to have free access to pellets and tap water and were exposed to natural light-dark cycle and room temperature. All animals were handled according to standard protocols for the use of Laboratory animals.

In-vivo anti-inflammatory procedure: The in-vivo anti-inflammatory studies were carried out using albumin and histamine induced paw inflammation in mice and xylene induced ear edema on mice (Okokon, 2012; Anosike et al., (2013); vetriselvan et al., (2013).

Egg albumin induced inflammation in mice: Adult albino mice of $20-30 \mathrm{~g}$ were denied of food for 24 hours. The mice were divided into groups of seven with four mice each. Group 1 received $10 \mathrm{ml} / \mathrm{kg}$ of distilled water, group 2 received $10 \mathrm{mg} / \mathrm{kg}$ diclofenac, groups 3,4 and 5 received the di-herbal extract at different doses of $50 \mathrm{mg} / \mathrm{kg}$ Euphorbia hirta $(\mathrm{EH})$ and $100 \mathrm{mg} / \mathrm{kg}$ Lactuca virosa (WL), $100 \mathrm{mg} / \mathrm{kg} \mathrm{EH}$ and $50 \mathrm{mg} / \mathrm{kg} \mathrm{WL}, 100 \mathrm{mg} / \mathrm{kg}$ EH and $100 \mathrm{mg} / \mathrm{kg} \mathrm{WL}$, respectively. Group 6 received $100 \mathrm{mg} / \mathrm{kg} \mathrm{EH}$; Group 7 received $100 \mathrm{mg} / \mathrm{kg} \mathrm{WL}$. The initial paw size of all the animals were measured with a Vernier caliper before introduction of $0.1 \mathrm{ml}$ of egg albumin at the left hind paw. The diameter of inflammation was measured at $0,30,60$ and 120 minutes respectively. The paw swelling at each time was calculated as the difference between the diameters at time $t_{a}$ and that of the initial paw diameter before induction $t_{0}$.

Histamine induced inflammation in mice: Adult albino mice of $20-30 \mathrm{~g}$ were denied of food for 24 hours. The mice were divided into groups of seven with four mice each. Group 1 received $10 \mathrm{ml} / \mathrm{kg}$ of distilled water, group 2 received $10 \mathrm{mg} / \mathrm{kg}$ diclofenac, groups 3,4 and 5 received the di-herbal extract at different doses of $50 \mathrm{mg} / \mathrm{kg}$ Euphorbia hirta (EH) and 100 $\mathrm{mg} / \mathrm{kg}$ Lactuca virosa (WL), $100 \mathrm{mg} / \mathrm{kg} \mathrm{EH}$ and 50 $\mathrm{mg} / \mathrm{kg} \mathrm{WL}, 100 \mathrm{mg} / \mathrm{kg} \mathrm{EH}$ and $100 \mathrm{mg} / \mathrm{kg} \mathrm{WL}$, respectively. Group 6 received $100 \mathrm{mg} / \mathrm{kg} \mathrm{EH;} \mathrm{Group}$ 7 received $100 \mathrm{mg} / \mathrm{kg} \mathrm{WL}$. The initial paw size of all the animals were measured with a Vernier caliper before introducing of $0.1 \mathrm{ml}$ of $1 \%$ histamine into the sub plantar surface of the right hind paw. The diameter of inflammation was measured at $0,30,60$ and 120 minutes respectively. The paw swelling at each time was calculated as the difference between the diameter at time $t_{a}$ and that of the initial paw diameter before induction $\mathrm{t}_{0}$.
Xylene induced inflammation on mice: The mice of 20 $-30 \mathrm{~g}$ were divided into seven groups of four animals each. Group 1 received $\mathrm{ml} / \mathrm{kg}$ of distilled water, Group 2 received $2 \mathrm{mg} / \mathrm{kg}$ dexamethasone, Groups 3,4 and 5 received the di-herbal extract at different doses of $50 \mathrm{mg} / \mathrm{kg}$ Euphorbia hirta(EH) and $100 \mathrm{mg} / \mathrm{kg}$ Lactuca virosa (WL), $100 \mathrm{mg} / \mathrm{kg} \mathrm{EH}$ and $50 \mathrm{mg} / \mathrm{kg}$ $\mathrm{WL}, 100 \mathrm{mg} / \mathrm{kg}$ EH and $100 \mathrm{mg} / \mathrm{kg} \mathrm{WL}$, respectively. Group 6 received 100 mg/kg EH; Group 7 received $100 \mathrm{mg} / \mathrm{kg} \mathrm{WL}$. One hour later, $30 \mu \mathrm{l}$ of xylene was applied to the inner and outer surface of the right ear using a microliter pipette to induced edema in each mouse in each group. The animals were sacrificed by cervical dislocation and two ears copped off, sized and weighed after 3 hours of xylene application. The antiinflammatory activity (AIA) was stated as percentage inhibition

$$
\% A I A=\frac{\mathrm{MwtC}-\mathrm{MwtT}}{\mathrm{MwtC}} \times 100
$$

Where MwtC $=$ Mean weight of control MwtT $=$ mean weight of test

In-vitro experimental model: The in-vitro antiinflammatory studies were carried out using erythrocyte membrane stabilization assay by heat induced hemolysis and inhibition of protein denaturation assay (Sakat et al., (2010); Jayasuriaya et al., (2017).

Erythrocyte Membrane stabilization: The combination containing $1 \mathrm{ml}$ of extract of different concentration $(1-3 \mathrm{mg} / \mathrm{ml})$ and $1 \mathrm{ml}$ of the erythrocyte suspension prepared. Aspirin was used as standard (1 $-3 \mathrm{mg} / \mathrm{ml}$ ), the mixture as that of the extract. The combination mixed gently and incubated, 30 minutes in a water bath at $60^{\circ} \mathrm{C}$. Tubes were cooled below running water after incubation. The combination was centrifuged at $2500 \mathrm{rpm}$ for 10 minutes and the absorbance of the supernatant was taken at $560 \mathrm{~nm}$ with spectrophotometer. Percentage inhibition of hemolysis was calculated as follows:

$$
\% I H=\frac{\mathrm{AC}-\mathrm{AT}}{\mathrm{AC}} \times 100
$$

Where $\mathrm{IH}=$ Percentage inhibition of hemolysis

Inhibition of protein denaturation assay: The reaction combination comprising of various concentrations of plant extract $(1-3 \mathrm{mg} / \mathrm{ml}), 2 \mathrm{ml}$ of egg albumin and $10 \mathrm{ml}$ of phosphate buffered saline was added to the reaction mixture. Aspirin $(1-3 \mathrm{mg} / \mathrm{ml})$ is used as the standard. The combination was incubated at $37{ }^{\circ} \mathrm{C}$ for 15 minutes and heated at $70{ }^{\circ} \mathrm{C}$ for 5 minutes again. The reaction combinations were cooled with running 
water and their absorbance were measured at $660 \mathrm{~nm}$ using a spectrophotometer. Percentage inhibition was calculated.

$$
\% I P D=\frac{\mathrm{AC}-\mathrm{AT}}{\mathrm{AC}} \times 100
$$

Where IPD $=$ Percentage inhibition of protein denaturation; $\mathrm{AC}=$ Absorbance of control; $\mathrm{AT}=$ Absorbance of test

Histology of the inflamed ears: The inflamed ears from the xylene induced ear oedema were chopped off. One ear was taken from each group and one ear from a non-inflamed mouse.

The ears were fixed in $10 \%(\mathrm{~V} / \mathrm{V})$ formal saline, routinely pressed and embedded in paraffin wax, Paraffin sections of 5.0-micron thickness were cut using a rotary microtome, fixed unto glass slides and stained with hematoxylin and eosin for histological examination.

The slides were examined by a histologist under the compound light microscope provided with camera and image capture software.

Statistical analysis: Results are expressed as mean \pm SEM. The differences between experimental groups were compared by one-way analysis of variance followed by multiple comparison tests, using the software GraphPad prism.

\section{RESULT AND DISCUSSION}

Albumin and histamine induced inflammation in mice: This study shows that di-herbal formulation (Euphorbia hirta and Lactuca virosa) at all doses, Euphorbia hirta (100 mg/kg), Lactuca virosa (100 $\mathrm{mg} / \mathrm{kg})$ and the standard drug $(10 \mathrm{mg} / \mathrm{kg}$ of Diclofenac) reduced the diameter of inflammation in both albumin and histamine induced paw inflammation (Table 1 and 2). Egg albumin and histamine in inflammatory model are well known animal model widely used to study anti-inflammatory activities of medicinal plants or anti-inflammatory agents (Benly, 2015). Egg albumin facilitates its inflammatory effect by initiating the discharging of histamine and 5-HT (5-hydroxytryptamine or serotonin) while histamine cause inflammation by activating increased vascular permeability, leading to amplified blood flow and vasodilation. This result to inflammatory signs such as redness and swelling (Benly, 2015). The anti-inflammatory effect of diherbal formulation (Euphorbia hirta and Lactuca virosa), Euphorbia hirta, and Lactuca virosa alone is comparable to diclofenac the standard drug (table 1and 2). Diclofenac is a non-steroidal anti-inflammatory drug that acts by inhibiting the enzyme cyclooxygenase which leads to the inhibition of prostaglandin synthesis responsible for inflammation (Kilci et al., (2016). The anti-inflammatory activities of the di-herbal formulation could be credited to the inhibition of cyclooxygenase an enzyme that lead to prostaglandin production.

Table 1: The effect of the di-herbal formulation (Euphorbia hirta and lactuca virosa) on albumin induced paw inflammation in mice

\begin{tabular}{llllll}
\hline \multirow{2}{*}{ Groups } & \multicolumn{4}{c}{ Diameter of Inflammation $(\mathrm{Mm})$} & \multirow{2}{*}{$\begin{array}{c}\text { Inflammation } \\
\text { Inhibition }\end{array}$} \\
\cline { 2 - 5 } & $0 \mathrm{~min}$ & $30 \mathrm{~min}$ & $60 \mathrm{~min}$ & $120 \mathrm{~min}$ & \\
\hline CONIR OL & $1.41 \pm 0.27$ & $1.80 \pm 0.24$ & $2.24 \pm 0.23$ & $2.32 \pm 0.24$ & \\
STANDARD & $0.58 \pm 0.13$ & $1.50 \pm 0.27$ & $0.70 \pm 0.14 * * *$ & $0.58 \pm 0.14 * * * *$ & 75.03 \\
50EH +100WL & $1.02 \pm 0.49$ & $1.30 \pm 0.45$ & $1.21 \pm 0.24 *$ & $0.87 \pm 0.28 * * *$ & 62.55 \\
100EH+50WL & $0.90 \pm 0.28$ & $1.20 \pm 0.26$ & $0.46 \pm 0+.10 * * * *$ & $0.50 \pm 0.15 * * * *$ & 78.69 \\
$100 \mathrm{EH}+100 \mathrm{WL}$ & $1.03 \pm 0.54$ & $0.50 \pm 0.12 *$ & $0.33 \pm 0.10 * * * *$ & $0.45 \pm 0.07 * * * *$ & 80.71 \\
$100 \mathrm{EH}$ & $0.80 \pm 0.19$ & $1.07 \pm 0.38$ & $0.59 \pm 0.34 * * *$ & $0.41 \pm 0.16 * * * *$ & 82.44 \\
100WL & $1.20 \pm 0.64$ & $0.41 \pm 0.18 *$ & $0.16 \pm 0.04 * * * *$ & $0.15 \pm 0.03 * * * *$ & 93.41 \\
\hline
\end{tabular}

$E H=$ Euphorbia Hirta $;$ WL $=$ Wild lettuce (Lactuca virosa). Each value represents the mean $\pm \operatorname{SEM}(\mathrm{n}=4)$

Table 2: The effect of the di-herbal formulation (Euphorbia hirta and lactuca virosa) on histamine induced paw inflammation in mice

\begin{tabular}{llllll}
\hline Groups & \multicolumn{2}{l}{ Diameter of Inflammation (Mm) } & $\begin{array}{l}\text { \%Inflammation } \\
\text { Inhibition }\end{array}$ \\
\cline { 2 - 5 } & $0 \mathrm{~min}$ & $30 \mathrm{~min}$ & $60 \mathrm{~min}$ & $120 \mathrm{~min}$ & \\
\hline CONTROL & $0.83 \pm 0.21$ & $1.33 \pm 0.08$ & $1.03 \pm 0.23$ & $0.83 \pm 0.211$ & \\
STANDARD & $1.45 \pm 0.20$ & $1.16 \pm 0.11^{*}$ & $0.39 \pm 0.16^{* * * *}$ & $0.29 \pm 0.09^{* * *}$ & 68.00 \\
50EH +100WL & $1.96 \pm 0.08$ & $0.40 \pm 0.04^{* *}$ & $0.20 \pm 0.04^{* * *}$ & $0.19 \pm 0.05^{* * *}$ & 77.05 \\
100EH+50WL & $1.21 \pm 0.44$ & $0.70 \pm 0.13$ & $0.29 \pm 0.10^{* *}$ & $0.20 \pm 0.06^{* * *}$ & 76.45 \\
100EH+100WL & $1.27 \pm 0.23$ & $0.28 \pm 0.07$ & $0.18 \pm 0.06^{* * *}$ & $0.30 \pm 0.21^{* * *}$ & 64.61 \\
100EH & $1.46 \pm 0.42$ & $0.54 \pm 0.31$ & $0.29 \pm 0.188^{* *}$ & $0.23 \pm 0.17^{* * *}$ & 72.83 \\
100WL & $1.48 \pm 0.25$ & $0.46 \pm 0.17$ & $0.15 \pm 0.05^{* * 8}$ & $0.23 \pm 0.07^{* * *}$ & 72.83 \\
\hline
\end{tabular}

Each value represents the mean $\pm S E M ; E H=$ Euphorbia hirta; $W L=$ Wild lettuce (Lactuca virosa) 
Table 3: The effect of the di-herbal formulation (Euphorbia hirta and Latuca virosa) on xylene induced ear inflammation in mice. Each value represents the mean $\pm \mathrm{SEM} ; \mathrm{EH}=$ Euphorbia hirta; $\mathrm{WL}=$ Wild lettuce (Lactuca virosa)

\begin{tabular}{|c|c|c|}
\hline Groupsa & \multicolumn{2}{|c|}{ Ear-Inflammation'(Mg) $\approx \%$ Inflammation'Inhibition } \\
\hline CONTROLA & $66.89 \pm 5.759$ & 9 \\
\hline STANDARD= & $48.46 \pm 2.96 *$ & 27.559 \\
\hline $50 \mathrm{EH}+100 \mathrm{WL}$ & $36.75 \pm 5.19 * 8 * 9$ & $45.06 \mathrm{a}$ \\
\hline $100 \mathrm{EH}+50 \mathrm{WL}=$ & $36.51 \pm 4.58 * 8 * 9$ & 45.428 \\
\hline $100 \mathrm{EH}+100 \mathrm{WL}=$ & $45.79 \pm 3.51 \%$ & $31.54 \mathrm{~g}$ \\
\hline $100 \mathrm{EH}=$ & $42.53 \pm 2.23 * *$ & 36.420 \\
\hline $100 \mathrm{WL}$ & $42.53 \pm 2.23 * 8$ & 36.428 \\
\hline
\end{tabular}

Xylene induced ear inflammation on mice: In xylene induced ear inflammation, di-herbal formulation (Euphorbia hirta and Lactuca virosa), Euphorbia hirta, Lactuca virosa alone and the standard drug (2 $\mathrm{mg} / \mathrm{kg}$ of Dexamethasone) and the di-herbal formulation reduced the weight of inflammation (Table 3). Xylene initiate inflammation by the release of histamine, kinin, fibrinolysin and phospholipase $\mathrm{A}_{2}$, these inflammatory mediators induce edema by vasodilation and increased vascular permeability (Zhang et al., (2015); Xu et al., (2014). The di-herbal formulation (Euphorbia hirta and Lactuca virosa) shows a better anti-inflammatory activity compared to the standard dexamethasone (Table 3). Dexamethasone is an agonist of the glucocorticoid receptor, it inhibits production of inflammatory cells and suppresses expression of inflammatory mediators (Vetriselvan et al., (2013). The anti-inflammatory effect of the di-herbal formulation may be due to the inhibition of the production of inflammatory cells, suppressing the expression of inflammatory mediators.

Histology of the inflamed ears in xylene induced ear inflammation on mice: Histology slide of ear in mice showing normal stratified squamous epithelium with normal dermal tissue (Plate 1). Plate 2 shows histology of inflamed ear showing normal keratinized stratified squamous epithelium and some inflammatory cells in inflamed control. Plate 3 shows histology of inflamed ear with normal stratified squamous epithelium and normal dermal structures at $2 \mathrm{mg} / \mathrm{kg}$ of dexamethasone. Histology of inflamed ear with stratified squamous epithelium, presence of vacuoles and lymphocytic infiltrates at the di-herbal dose of 50 $\mathrm{mg} / \mathrm{kg}$ Euphorbia hirta and $100 \mathrm{mg} / \mathrm{kg}$ Lactuca virosa. Plate 5 shows the histology of inflamed ear with stratified squamous epithelium, lymphocytic infiltrates at the di-herbal dose of $100 \mathrm{mg} / \mathrm{kg}$ Euphorbia hirta and $50 \mathrm{mg} / \mathrm{kg}$ Lactuca virosa. Plate 6 and 7 shows histology of inflamed ear with stratified squamous epithelium, presence of vacuoles and few lymphocytic infiltrates in an edematous dermal layer at the di-herbal dose of $100 \mathrm{mg} / \mathrm{kg}$ Euphorbia hirta and $100 \mathrm{mg} / \mathrm{kg}$ Lactuca virosa, $100 \mathrm{mg} / \mathrm{kg}$ of Euphorbia hirta and $100 \mathrm{mg} / \mathrm{kg}$ Lactuca virosa. The histology result shows that the standard drug (dexamethasone) and the aqueous extract of Euphorbia hirta and lactuca virosa were able to ameliorate the effect of inflammation caused by xylene.

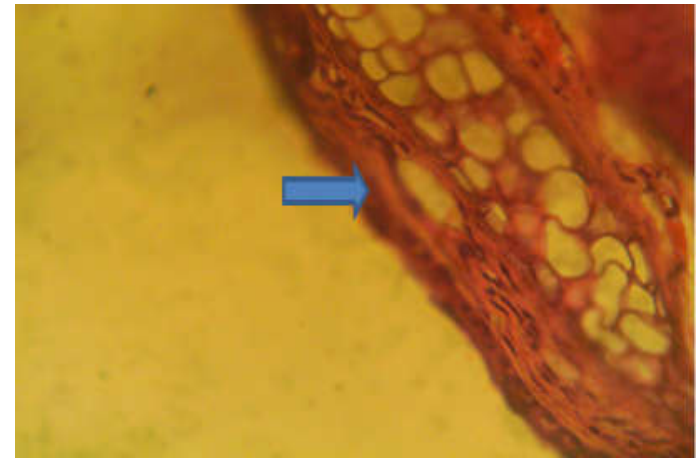

Plate 1: Histology of ear in mice showing normal stratified squamous epithelium (arrow) with normal dermal tissue (X100)

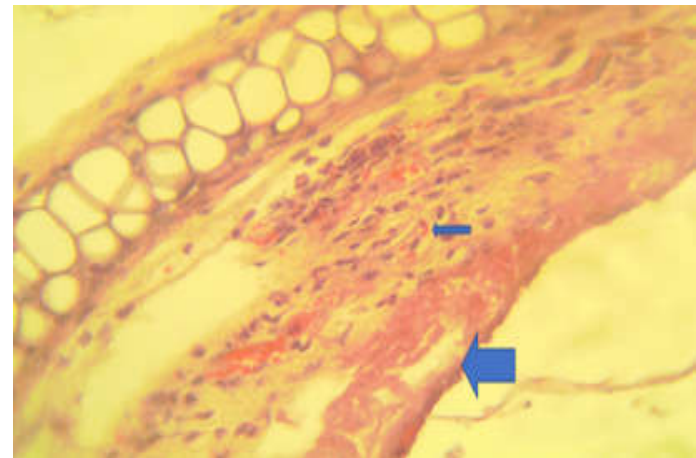

Plate 2: Histology of inflamed ear showing normal keratinized stratified squamous epithelium (thick arrow) and some inflammatory cells (thin arrow) in inflamed control group. (X400)

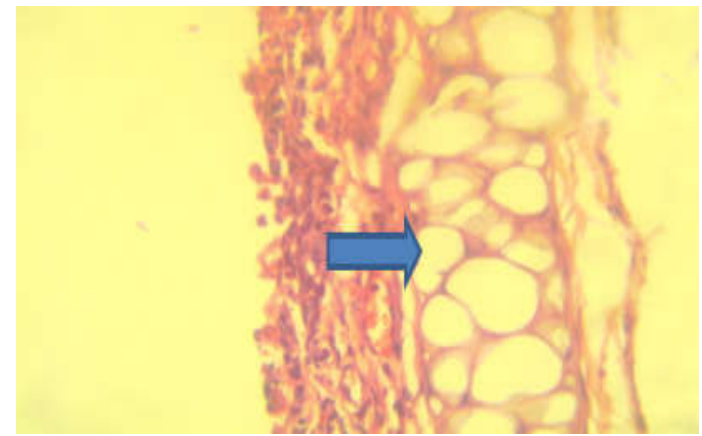

Plate 3: Histology of inflamed ear showing a normal stratified squamous epithelium and normal dermal structures at $2 \mathrm{mg} / \mathrm{kg}$ of dexamethasone. (X400) 


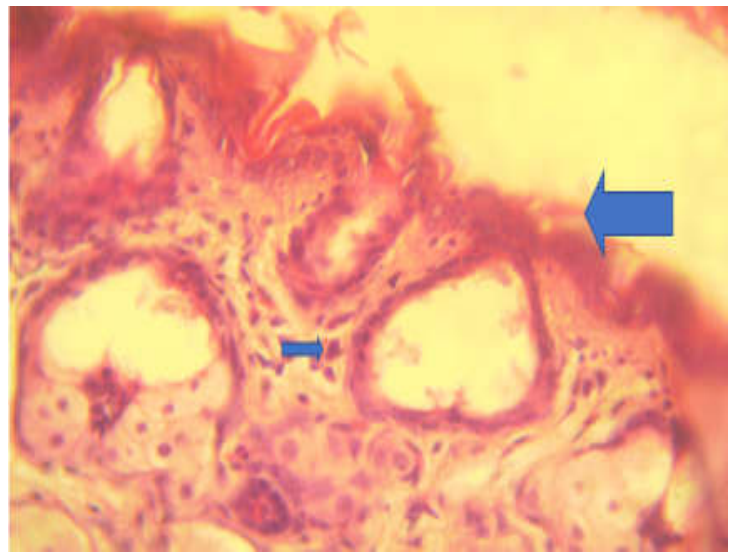

Plate 4: Histology of inflamed ear showing stratified squamous epithelium (thick arrow), with presence of vacuoles and lymphocytic infiltrates (thin arrow) at the di-herbal dose of 50 $\mathrm{mg} / \mathrm{kg} \mathrm{EH}$ and $100 \mathrm{mg} / \mathrm{kg} \mathrm{WL}$. (X400)

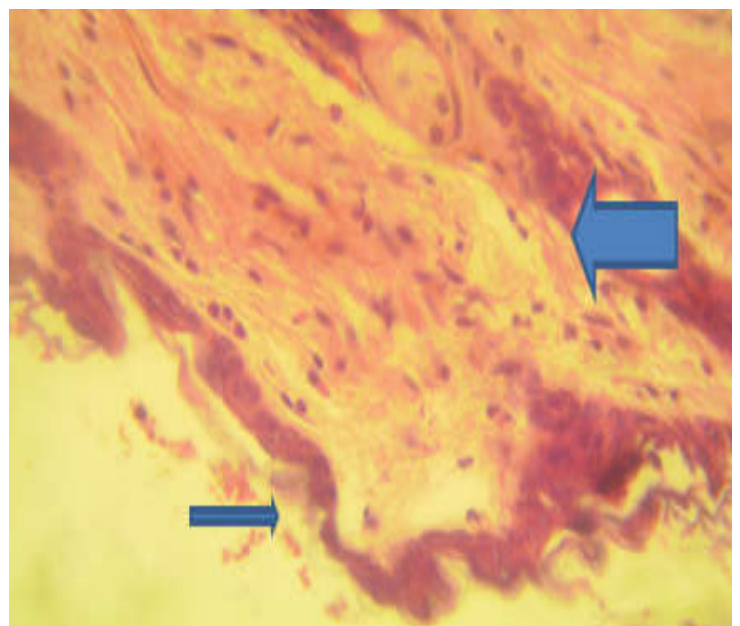

Plate 5: Histology of inflamed ear showing stratified squamous epithelium (thick arrow), lymphocytic infiltrates (thin arrow) at the di-herbal dose of $100 \mathrm{mg} / \mathrm{kg} \mathrm{EH}$ and $50 \mathrm{mg} / \mathrm{kg} \mathrm{WL}$. (X400)

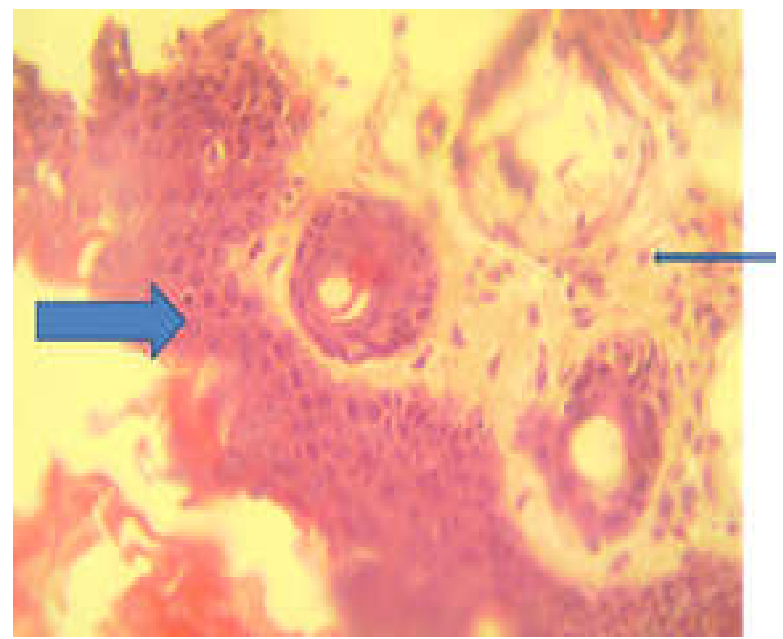

Plate 6: Histology of inflamed ear showing stratified squamous epithelium (thick arrow), with presence of vacuoles and few lymphocytic infiltrates (thin arrow) in an edematous dermal layer at the di-herbal dose of $100 \mathrm{mg} / \mathrm{kg}$ EH and $100 \mathrm{mg} / \mathrm{kg} \mathrm{WL}$ (X400)

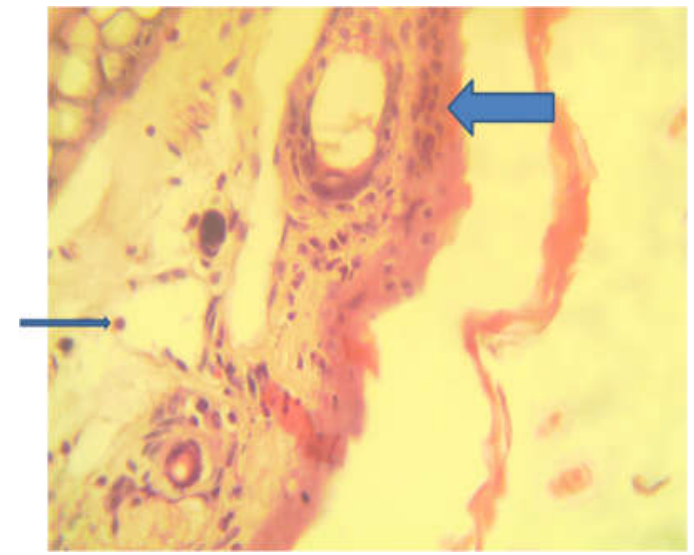

Plate 7: Histology of inflamed ear showing stratified squamous epithelium (thick arrow), with presence of vacuoles and lymphocytic infiltrates (thin arrow) in an edematous dermal layer at a dose of $100 \mathrm{mg} / \mathrm{kg}$ of EH. (X400)

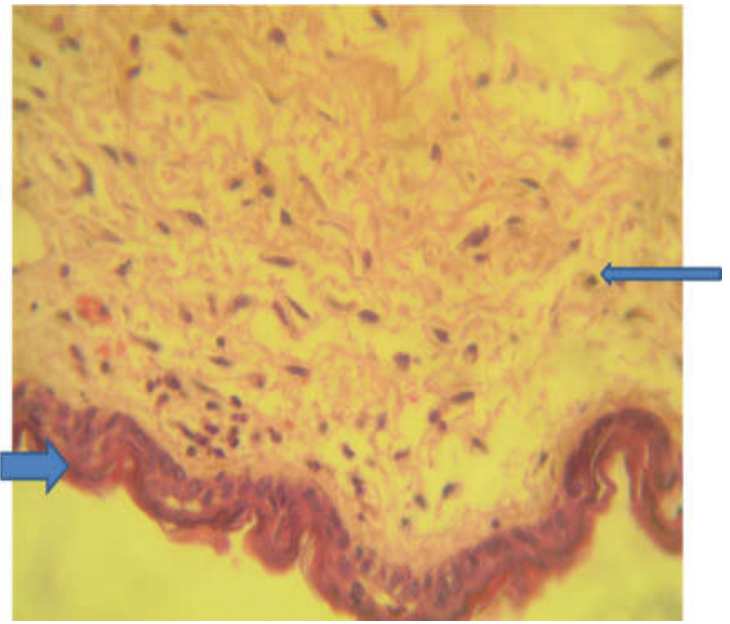

Plate 8: Histology of inflamed ear showing stratified squamous epithelium (thick arrow), with lymphocytic infiltrates (thin arrow) in an oedematous dermal layer at the dose of $100 \mathrm{mg} / \mathrm{WL}$. (X400).

Protein denaturation and heat induced hemolysis: The in-vitro anti-inflammatory study revealed that of Euphorbia hirta and lactuca virosa has the ability to inhibit thermally induced protein denaturation compared aspirin (Figure 1 and 2). The denaturation of protein is a well-documented cause of inflammation and rheumatoid arthritis (Kirtikar and Basu, (1999). Aspirin as a non-steroidal anti-inflammatory drug has been shown to have the ability to inhibit thermally induced protein denaturation (Garg, 2001).

Euphorbia hirta and Lactuca virosa in erythrocyte membrane stabilization assay were able to stabilize the erythrocyte membrane by inhibiting heat which would have lysed the erythrocyte (Figure 3 and 4). Stabilization of lysosomal membrane is important in limiting the inflammatory response by preventing the release of lysosomal constituents which causes further tissue inflammation and damage upon extracellular 
release. Aspirin, as a non-steroidal anti-inflammatory drug acts by inhibiting the lysosomal enzyme and stabilizing the lysosomal enzyme (Rajendran and Lakshmi, (2001). The human red blood cell membrane stabilization has been used as a method to study the invitro anti-inflammatory activity because the erythrocyte membrane is analogous to the lysosome membrane (Shenoy et al., (2010). Its stabilization implies that the extract may well stabilize lysosomal membranes.

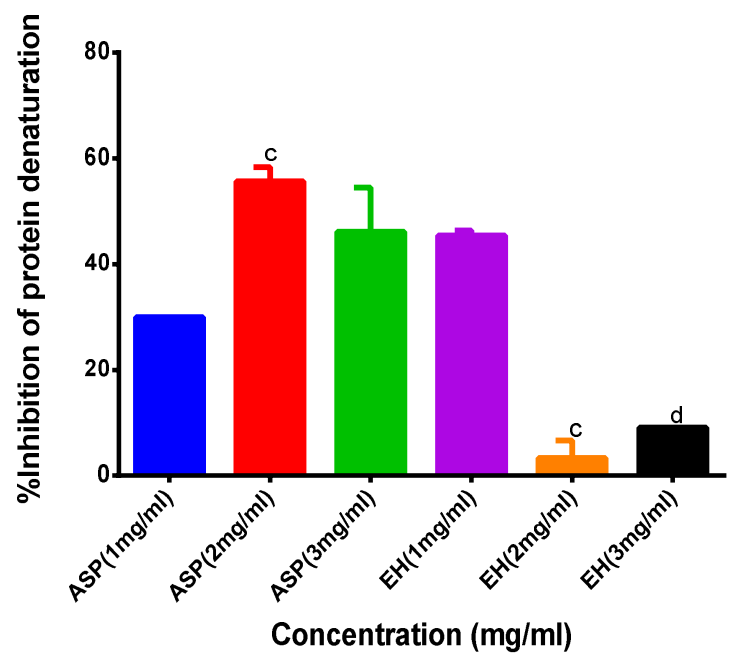

Fig 1: Effect of aqueous extract of Euphorbia hirta (EH) and aspirin (ASP) against protein denaturation. The aqueous extract of Euphorbia hirta showed inhibitory effect on protein denaturation by heat when compared $\left({ }^{\mathrm{d}} \mathrm{P}<0.05\right)$ to Aspirin. However, Aspirin showed a better inhibitory effect. Values are represented as Mean \pm SEM, $\mathrm{n}=3$.

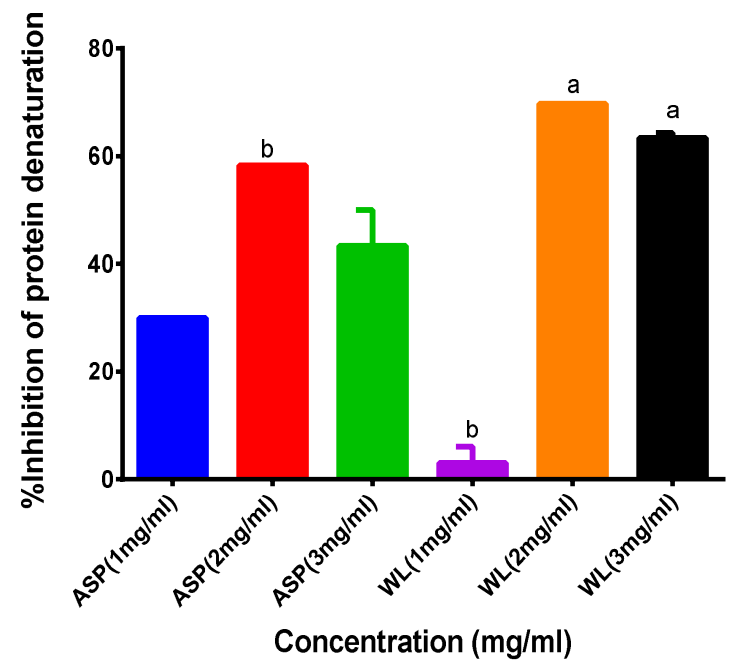

Fig 2: Effect of aqueous extract of Lactuca virosa (WL) and aspirin (ASP) against protein denaturation. The aqueous extract of Latuca virosa (Wild lettuce) showed inhibitory effect on protein denaturation by heat when compared $\left({ }^{\mathrm{a}} \mathrm{P}<0.001 ;{ }^{\mathrm{b}} \mathrm{P}>0.05\right)$ to Aspirin. However, the percentage inhibition of protein denaturation was greater than that seen in Aspirin (figure 4). Values are represented as Mean \pm SEM, $\mathrm{n}=3$.

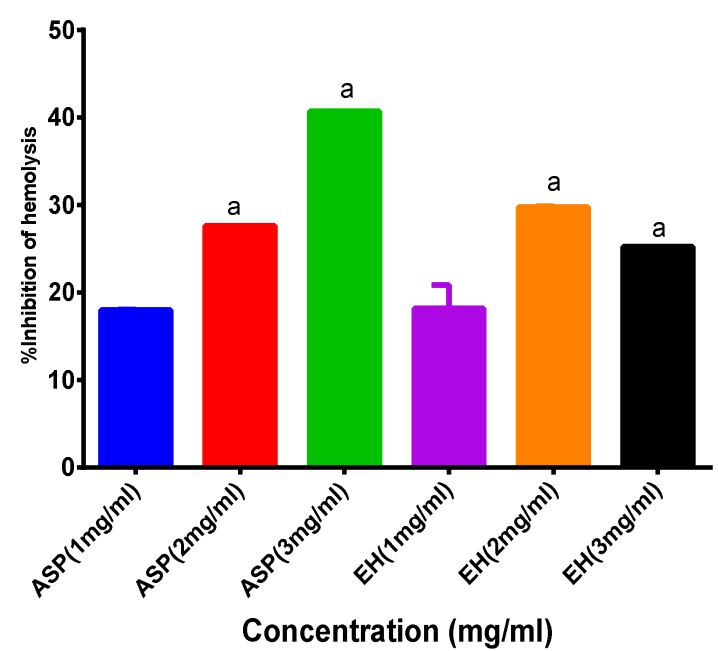

Fig 3: Red blood cell stabilizing effect of aqueous extract of Euphorbia hirta (EH) and aspirin (ASP). The aqueous extract of Euphorbia hirta showed inhibitory effect on inhibition of hemolysis when compared ( $\left.{ }^{\mathrm{a}} \mathrm{P}<0.0001\right)$ to Aspirin. However, Aspirin showed a better inhibitory effect. Values are represented as Mean \pm SEM, $\mathrm{n}=3$.

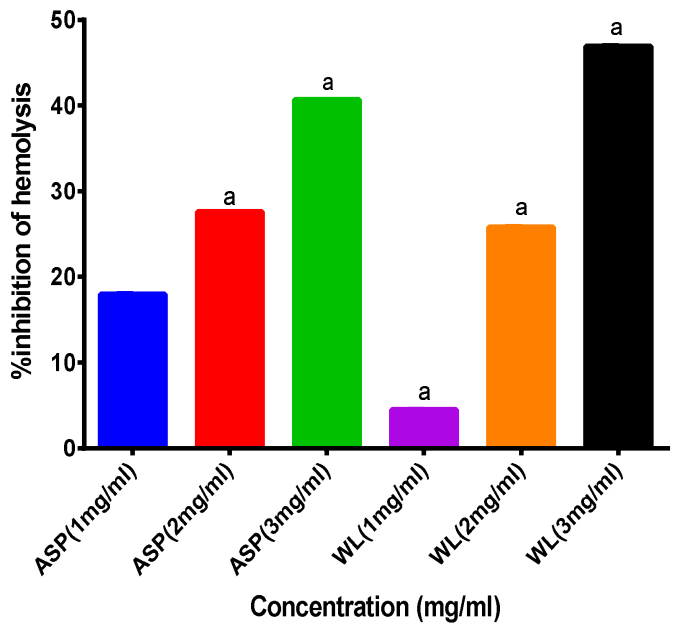

Fig 4: Red blood cell stabilizing effect of aqueous of Lactuca virosa (WL) and aspirin (ASP). The aqueous extract of Latuca virosa (Wild lettuce) showed inhibitory effect on inhibition of hemolysis when compared ( $\left.{ }^{\mathrm{a}} \mathrm{P}<0.0001\right)$ to Aspirin. Values are represented as Mean \pm SEM, $\mathrm{n}=3$.

Conclusion: This study shows that the aqueous extract of Euphorbia hirta and Lactuca virosa has antiinflammatory activities both in-vivo and in-vitro. The di-herbal formulation shows promise as a potent agent for conditions associated with inflammation.

\section{REFERENCES}

Anosike, AC; Onyechi, O; Lawrence, U; Ezeanyika, S; Chioma, A; Christopher, J (2003). The antiinflammatory activity of garden egg (Solanum aethiopicum) on egg albumin-induced oedema 
and granuloma tissue formation in rats. Inflammation Protocols 115-121

Benly, P (2015). Role of histamine in acute inflammation. J. Pharm. Sci. \& Res 7(6): $3733-$ 376

Dar, RA; Shahnawaz, M; Qazi, PH (2017). General overview of medicinal plants. JPHYTO 6(6): 349 $-351$

Darkwa, S; Darkwa, AA (2013). The use of indigenous green leafy vegetables in the preparation of Ghanaian dishes. J Food Process Technol 4:12

Garg, SC (2001). Ethnomedicine for snake bite. $J$. Medicinal and Aromatic Plant Sci. 5: 546-553

Jayasuriya, WJ; Sarveswaran, R; Suresh TS (2017). In vitro assays to investigate the anti-inflammatory activity of herbal extracts: a review. WJPR 6 (17): 131-141

Kirtikar, KR; Basu, BD (1999). Indian Medicinal Plants. 2nd edition, Bishen Sing, Dehradun, Mahendra Pal Sing publication. Pp 1655-1656

Pranabesh G; Chandreyi G; Shaktijit, D; Chandrima, D; Suprodip, M; Sirshendu, C (2019). Botanical description, phytochemical constituents and pharmacological properties of Euphorbia hirta Linn: a review. IJHSR 9(3): 273 - 286

Rajendran, V; Lakshmi, KS (2008). In vitro and in vivo anti-inflammatory activity of leaves of Symplocos cochinchinensis (Lour). J Pharmacol 3: $121-124$
Sakat, S; Juvekar, AR; Gambhire, MN (2010). In vitro antioxidant and anti-inflammatory activity of methanol extract of Oxalis corniculata Linn. Int J Pharma and Pharm Sci 2(1): 146-155

Shenoy, S; Shwetha, K; Prabhu, K; Maradi, R; Bairy, KL; Shanbhag, T (2010). Evaluation of antiinflammatory activity of Tephrosia purpurea in rats. Asian Pac J Trop Med 3(3): 193-195

Sunil, K; Rashmi, M; Dinesh, K (2010). Euphorbia hirta: Its chemistry, traditional and medicinal uses and pharmacological activities. Phcog Rev 4(7): $58-611$

Vetriselvan, S; Subasini, U; Velmurugan, C; Muthuramu, T; Shankar, J (2013). Antiinflammatory activity of cucumis sativus seed in carrageenan and xylene induced edema model using albino wistar rats. Int. J. of Biopharmaceutics 4(1): 34-37

World Health Organization, Geneva, Switzerland. 1998. Regulatory situation of herbal medicines: $A$ worldwide review. Pp.1-5

Xu, Q; Wang, Y; Guo, S; Shen, Z; Wang, Y; Yang, L (2014). Anti-inflammatory and analgesic activity of aqueous extract of Flos populi. $J$ Ethnopharmacol 152(3): 540—545

Zhang, Y; Shu, Z; Yin, L; Ma, L; Wang, X; Fu, X (2015). Anti-inflammatory and antinociceptive activities of non-alkaloids fractions from Aconitum flavum in vivo. Rev Bras Farmacogn 25(1): $47-52$ 